\title{
The Leadership of the Prophet The Role Model of Today's Leaders
}

\author{
Eka Safitri*, Muhammad Fatih Abdurrahman, Putri Fajriatin Qona'ah, Wahyu Nur \\ Aini \\ Department of Food Technology, Faculty of Agriculture, Jenderal Soedirman University \\ *eka.safitri@unsoed.ac.id
}

\begin{abstract}
In fact, every human being is a leader, either for himself or for others. The nature of leadership is closely related to a leader. Leadership is a trait that can influence, move or encourage others to achieve a predetermined goal. The essence of leadership in Islam leads a servant to true servitude to Allah. In Islam, a leader must be an example for his group, such as the Prophet Muhammad saw. The personality of the Prophet Muhammad saw. as a leader is exemplary because of his toughness which is not affected by the circumstances of the surrounding community which are still ignorant. This study aims to analyze the leadership style of the Prophet Muhammad that can be applied today. The data collection technique used reading and note-taking techniques and the data were analyzed using a qualitative descriptive. From the results of this study, it can be explained that the leadership style of the Prophet Muhammad that can be applied today is a democratic attitude. This study concludes that the Prophet Muhammad is a role model for leaders, even today leaders should apply the leadership style of the Prophet Muhammad who is religiously democratic.
\end{abstract}

Keywords: leadership; Prophet Muhammad; role models; today's leader

\begin{abstract}
Pada hakikatnya setiap manusia adalah seorang pemimpin, baik untuk dirinya sendiri atau orang lain. Sifat kepemimpinan erat kaitannya dengan seorang pemimpin. Kepemimpinan adalah sifat yang dapat mempengaruhi, menggerakkan atau mendorong orang lain agar dapat tercapai suatu tujuan yang telah ditentukan. Hakikat kepemimpinan dalam Islam mengantarkan seorang hamba kepada penghambaan sejati kepada Allah. Dalam agama Islam, seorang pemimpin harus menjadi teladan bagi kelompoknya, seperti contohnya Nabi Muhammad saw. Kepribadian Nabi Muhammad saw. sebagai seorang pemimpin patut diteladani karena ketangguhan beliau yang tidak terpengaruh pada keadaan masyarakat sekitarnya yang masih jahiliyah. Tujuan dari penelitian ini yaitu menganalisis gaya kepemimpinan Nabi Muhammad yang dapat diterapkan di masa sekarang. Teknik pengumpulan data menggunakan teknik membaca dan mencatat dan data dianalisis secara deskriptif kualitatif. Dari hasil studi ini, dapat dijelaskan bahwa gaya kepemimpinan Nabi Muhammad yang dapat diterapkan di masa sekarang adalah sikap demokratis. Penelitian ini menyimpulkan bahwa Nabi Muhammad adalah suri tauladan bagi para pemimpin, bahkan di masa sekarang para pemimpin hendaknya menerapkan gaya kepemimpinan Rasulullah saw. yang religious demokratis.
\end{abstract}

Kata Kunci: kepemimpinan; Nabi Muhammad; role model; pemimpin masa kini 


\section{A. Introduction}

The Qur'an explains that all humans on this earth one of their duties is to become a caliph (leader), therefore human beings cannot be separated from their duties, namely to be leaders, at least to lead themselves. A leader must be a good role model for those he leads. ${ }^{1}$ As we believe that the Prophet Muhammad was a leader who became a good role model for leaders. Prophet Muhammad was born and lived in a very bad society or known in the jahiliyah period. ${ }^{2}$ Therefore, Allah sent Prophet Muhammad to change the situation. It was not easy for the Prophet to preach at that time because there were so many threats and insults. But he managed to change his people from the era of ignorance into human beings who have manners and morals, with leadership and example possessed by him.

The importance of applying the leadership style of the Prophet today is because human life has entered the life of modernization or in the end times, where everyone can be easily influenced by negative things, including things that are forbidden by Allah. In addition, especially in Indonesia, the diversity is very large, for example, religious diversity, so that today tolerance is needed. This is what makes Rasulullah leadership style needs to be applied today, where the Prophet as the head of state or leader upholds the values of tolerance, always prioritizes noble character and is democratic.

The purpose of this study was to analyze the leadership traits of the Prophet Muhammad and analyze the application of the leadership style of the Prophet Muhammad in the present. This research uses a literature study methodology or literature study, namely by reading and understanding the writings related to the research title, sourced from several research journals using focus group discussion data collection techniques (focus group discussion). Meanwhile, in data analysis, this study uses a descriptive analysis model. This type of research is library research because this research uses theories that are reviewed using a qualitative descriptive approach.

The studies on leadership that has been carried out can be seen in the article entitled " Model Kepemimpinan Pendidikan Nabi Muhammad saw." in 2019, stated that there was a transformation of the leadership model of the Prophet Muhammad in education is through the transformation of public traits that are integrated with personal traits that are applied in the organization of educational institutions, especially as school principals. ${ }^{3}$

In another study conducted by Bashir Abdullatif et al entitled "Leadership in Islam: Views, Methods, and Suggestions in the Nigerian Islamic Organization" in 2020 explained that several actions and approaches to advance the management process in leading consist of applying leadership, enforcing followers, accommodate complexities, understand, and embrace fundamentals as vitally important. ${ }^{4}$ Furthermore, a study conducted by

\footnotetext{
${ }^{1}$ Muhamad Khoirul Umam, 'Imam Para Nabi : Menelusur Jejak Kepemimpinan Dan', 60 Jurnal AlHikmah, 6 no. (2018), 59-74.

${ }^{2}$ Mohd Shukri Hanapi, 'From Jahiliyyah To Islamic Worldview: In A Search Of An Islamic Educational Philosophy', International Journal of Humanities and Social Science, 3.2 (2013), 213-21.

${ }^{3}$ Nashria Rahayuning Tyas, 'Model Kepemimpinan Pendidikan Nabi Muhammad Saw', Muslim Heritage, 4.2 (2019) <https://doi.org/10.21154/muslimheritage.v4i2.1851>.

${ }^{4}$ Bashir Abdullatif and Mohd Farid Mohd Sharif, 'Leadership in Islam: Views, Methods, and Suggestions in the Nigerian Islamic Organization', International Journal of Academic Research in Business and Social Sciences, 10.3 (2020), 174-82 <https://doi.org/10.6007/ijarbss/v10-i3/7036>.
} 
Mubasyaroh in 2018 entitled "Pola Kepemimpinan Rasulullah: Cerminan Sistem Politik Islam" concluded that the Prophet's practice in leading Muslims is a form of implementation of Islamic politics. This is especially evident when he led the people in Medina by establishing an Islamic state, strengthening leadership, to embrace all groups, the Prophet made the Medina charter as a form of a peace agreement between Muslims and non-Muslims. In addition, the Prophet showed his exemplary and authority with the approval of Hudaibiyah..$^{5}$

The problems faced today in leadership are very complex problems. Where not only the system is the root of the problem, but the moral crisis of the leaders is also one of the triggers for the chaotic leadership conditions in the current era. Therefore, the author in this article examines the leadership of the Prophet Muhammad in the past that can be used as a role model in today's leadership. The location of the difference between this study and previous studies is in the study that took the theory of Imam al-Ghazali as an analytical knife of the ideal leader juxtaposed with the leadership of the Prophet Muhammad.

\section{B. Ideal Leader according to al-Ghazali}

All human activities on this earth require a leader to run well. In the verse of the Qur'an (qv. al-Baqarah/2: 30), which means: "Remember when your Lord said to the angels: "Indeed I want to make a caliph on earth". They said: "Why do you want to make (the caliph) on earth a person who will do mischief on it and shed blood when we always glorify you by praising you and purifying you?" God said: "Indeed I know what you do not know". 6

Khalifah is a person who can influence a group of people to achieve a common goal. To become a leader, a person must be able to have superior skills, especially in social values compared to other people. ${ }^{7}$ Furthermore, three things are always attached to a leader, namely power, authority, and ability. First, power is the ability, power, or authority given to leaders to influence or move members to do something. Second, authority is the superiority of a leader who can influence his members consciously so that they will voluntarily submit or obey the leader. Third, the ability is the technical or non-technical skills, abilities, or skills that are possessed beyond ordinary members. ${ }^{8}$ In the teachings of Islam, a leader who can be said to be good is someone who can deal fairly with all parties and is trustworthy in carrying out his duties. According to Imam Al Ghazali, the ideal leader is a broad intellectual, deep understanding of religion, and has a noble character.

\section{Intellectuality}

5 Mubasyaroh Mubasyaroh, 'Pola Kepemimpinan Rasulullah: Cerminan Sistem Politik Islam', Politea, 1.2 (2018), 95 <https://doi.org/10.21043/politea.v1i2.4488>.

${ }^{6}$ Watsiqotul Mardliyah, S. Sunardi, and Leo Agung, 'Peran Manusia Sebagai Khalifah Allah Di

Muka Bumi: Perspektif Ekologis Dalam Ajaran Islam', Jurnal Penelitian, 12.2 (2018), 355 <https://doi.org/10.21043/jp.v12i2.3523>.

${ }^{7}$ Nayal Rashed Mukred Mohsen, 'Leadership from The Qur'an Relationship Between Taqwa, Trust and Business Leadership Effectiveness' (University Sains Malaysia, 2007) <http://digilib.unila.ac.id/4949/15/BAB II.pdf>.

8 Jaman Abdulrheem and Hamdan Alzahrani, 'Prophet Muhammad's Leadership and the Leadership of the Modern Saudi Arabia', International Journal of Business Social Science, 8.8 (2017), 16063. 
Intellect is the light of the spirit which can be in the form of knowledge to guide a person's way to guide him in doing something. Intellect is also the difference between living things, such as animals or plants with humans. Based on the explanation from the Book of Ihyā'Ulum ad-Dn Juz I, Imam al-Ghazali classifies reason into four levels. ${ }^{9}$

First, Intellect means intelligence, which belongs to all humans. This intelligence can distinguish humans from animals or other creatures. This mind has been given by Allah swt from birth into the world as capital to live. Second, Intellect means understanding, grows in humans from childhood, and continues to grow until we are old. It is this mind that can distinguish what is right or wrong, the sensitivity depends on how the person has trained his mind since childhood. Third, Intellect means knowledge, which is born after experiencing teaching and gaining experience. Intellect is the cause of science in the developing world and gives birth to a lot, height, and breadth of knowledge, both natural science and social science. Fourth, Intellect means ma'rifah, which is the highest level of all levels of reason. That is human spiritual realization who realizes the consequences of something, and brings it to the nobility of character, and leads it to Allah swt.

For scientists, the reason is the highest wealth, while ignorance is miserable poverty. With reason, one can gain knowledge. Knowledge can be a light in the dark. Knowledge is the leader and reason is the follower

\section{Religion}

Religion is the most important thing during life in this world. This important thing is needed by everyone, even though sometimes that person doesn't realize it. Religion can be a moral guide for a person's life because of the teachings contained in it. ${ }^{10}$ The thing that can grow when we are religious is faith. Faith is a commitment to religion. Imam alGhazali emphasized that faith is the highest level of justification so that there is no longer any doubt in his heart and a person who believes does not feel he will make mistakes in his heart. If he has reached the stage of justification in his heart, then that person can be said to be a believer in the sight of Allah.

Imam al-Ghazali likens faith in the heart to ten roots and ten branches. The strongest root is belief in the heart. All knowledge and belief embedded in the heart is the basic principle of faith. Furthermore, being obedient and being just is a branch of faith. If the branch is not fertile, it can be ascertained that there is a problem at the root. Leaders who can increase their faith will receive the inheritance of the power of faith from the Prophet Muhammad.

\section{Morals}

Morals are an important element in humans, as well as in Islam, and are the essence of religious teachings. As in the Qur'an, the contents of which call on mankind to do good and stay away from bad deeds, to be fair and not to cheat, and forbid to no wrong doing in any form of activity and to anyone. According to Imam al-Ghazali, moral strength is the

${ }^{9}$ Ade Afriansyah, 'Konsep Pemimpin Ideal Menurut Al-Ghazālī', Nalar: Jurnal Peradaban Dan Pemikiran Islam, 1.2 (2018), 82 〈https://doi.org/10.23971/njppi.v1i2.905〉.

${ }^{10}$ Ilhamda Azis, 'Keteladanan Sifat Rasullah Muhammad SAW Dalam Etika Profesi Akuntan Publik', E-Jurnal Akuntansi, 30.5 (2020), 1142 <https://doi.org/10.24843/eja.2020.v30.i05.p06〉. 
ability to manage and control oneself from actions that lead to destructive ones. A person can be said to have moral strength if he fulfills the following four things. First, a high inclination in goodness and truth. Second, being able to distinguish between good and bad. Third, being able to do the good and leave the bad. Fourth, In correlation with worship, morality will depend on it. The obligations in Islam and the worship we do mean moral education. It is also a means of building morals, getting used to, and holding fast to good behavior, even though various obstacles occur in front of him. To have an optimal effect, the worship that is done should not be considered or felt only because of an obligation. However, it needs to be done wholeheartedly with a strong inner attitude.

Noble morality is one of the ideal criteria for a leader. Leaders are role models for the people or their members, so as much as possible, a leader can be a good example. Furthermore, good character is a reflection of the sincerity of people who fear Him. Meanwhile, bad morals are poison for the soul so that it will lead us to bad things. Morals are a picture of the state of the soul that resides in it. From this mental state, unconscious actions will emerge that we do. If the action is good and commendable, then it is called good character. Meanwhile, if the action leads to virtue then it is called bad character.

\section{Traits that Became the Foundation of the Leadership of the Prophet Muhammad}

The nature or style of a person in leading is called leadership. A person's leadership can reflect his personality. In Islam, a person can be oriented to be a good leader to the Prophet Muhammad because during his life he did noble things so that we can imitate him. One of the extraordinary things that the Prophet Muhammad saw., was able to revolutionize ignorance in the city of Mecca and spread the teachings of Islam (preaching) for 22 years until it was finally accepted by the whole world because of him as a leader of Islam. Even so, this happened because of the permission of Allah swt.

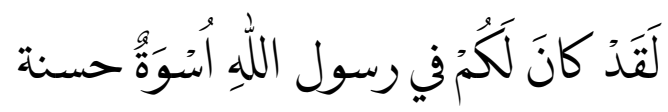

Indeed, the Messenger of Allah has been a good role model for you (qv. al-Ahzab/33: 21).

Based on the use of the word, there are many dictions of the word leadership, such as khalifah which means representative, representative, or replacement. This term first appeared after the leadership of the Prophet Muhammad replaced by the companions of the prophet. In Islam, this term was used for the first time by Abu Bakr when he was appointed the first caliph of Islam after the death of the Prophet Muhammad. In his inauguration speech as the leader at that time, Abu Bakr referred to himself at that time as the Caliph of the Prophet which means the successor of the Prophet. Therefore, the use of the word caliph relates to previous prophetic duties and continuing the missions of the apostles, one of which is broadcasting the religion of Islam. In addition, there is the word ulil amri which means the highest leader in Islamic society. The word ulil amri is mentioned in the Quran once in qv. an-Nisa/4.

As Muslims who live in the last days, we are the people of the Prophet Muhammad because he is the last prophet as well as the closing of the prophets. He is also a role model as a leader. His successful leadership is widely used as a benchmark that is applied in 
every era. In many ways, he can be used as an example of an ideal figure. Therefore, we must imitate the Prophet Muhammad saw. because they have perfect morals and ideal traits both personally and when socializing in society.

\section{Personal characteristics of the Prophet Muhammad}

First, trust. Amanah means trustworthy. This can be in the form of words or behavior. The proof is the Prophet Muhammad always tell the truth to get the title AlAmin. In terms of honesty, there must be news that explains the call of the Prophet Muhammad saw. to his people, to be honest in every situation, wherever and whenever it is. Ubaidillah Ibn Shamit r.a. said that the Messenger of Allah said, "Guarantee me six things from you, I guarantee for you paradise, these six things are: when you speak truthfully, keep your promises when you promise if you are trusted, fulfill your trust, keep your promises." your private parts (from disobedience), keep your eyes low (from all that is forbidden to see) and hold your hands (from taking what is unlawful)". (HR. Imam Ahmad). ${ }^{11}$

Second, tabligh. Prophet Muhammad saw. is a human chosen as the messenger of Allah SWT. to spread the teachings of Islam. All orders from Allah Swt. always conveyed to his followers with nothing to hide. He never added a word or two of Allah's commands that were conveyed through the intercession of the angel Gabriel. The first revelation came down on the 17th of Ramadan, namely qv. al-Alaq/96:1-5 is the proof. Since then he has become a messenger of Allah SWT. with the task of calling, inviting, and warning people to worship only Allah. The task also means that he must lead the $d a^{\prime} i$ of mankind to the straight path and stop from arbitrariness by denying Allah SWT. ${ }^{12}$

Third, fathonah. One of the blessings given to the Prophet Muhammad, namely in the form of extraordinary intelligence. This is evidenced by all the problems that come to be solved by the Prophet Muhammad. His intelligence in seeing this opportunity can be seen from the way he does his da'wah. The first da'wah was shown to people who lived with him, preached to those who were friends with him, preached to those who were close to him, after that, the Prophet Muhammad preached openly to the wider community, namely the Quraysh community and the people of Mecca in general. ${ }^{13}$

Fourth, charismatic. Rasulullah saw. has an ideal physique, has a noble character, and is honorable. This perfection is not owned by anyone except him. The position of the Prophet is like spirit and soul. The people's attachment to him is very strong. This causes his followers to be willing to fight to the last drop of blood

Fifth, strong self confidence. Prophet Muhammad saw. is a descendant of the Arabs. As is well known that Arabs have a will or determination that never subsides by anything. When they want something, then nothing can hinder and discourage them.

Sixth, high commitment. The high commitment that the Prophet had influenced his

11 Sakdiah, 'Karakteristik Kepemimpinan Dalam Islam ( Kajian Historis Filosofis ) Sifat-Sifat Rasulullah', Jurnal Al-Bayan, 22.33 (2016), 29-49.

${ }^{12}$ Sakdiah.

${ }^{13}$ Sakdiah. 
leadership style. ${ }^{14}$ As we know, in his preaching he always experienced severe trials. Even so, the Prophet never complained or felt tired of the burden he carried. This happens because it is solely for the pleasure of Allah SWT.

Seventh, hard worker. From a young age, the Prophet Muhammad was a hard worker. When he was an early teenager, he worked herding goats in Bani Sa'ad bin Bakr for a few dinars. Furthermore, when he was 25 years old, he traded in the land of Sham with Khadijah's capital.

\section{Prophet Muhammad's Social Character.}

Social nature here means the relationship of the Prophet with the surrounding community or his interaction with other people or the general public, including good communication, Close to people around, Always Discuss, Likes to Give Praise and Respect Others. ${ }^{15}$

First, good communication. In conveying a message, good communication skills are needed so that the message is conveyed and can be understood by the recipient. In terms of delivering the revelation of Allah, the Prophet Muhammad was able to convey His message well. The message conveyed by the Prophet Muhammad can affect a person's mind, heart, and even soul. It is proven by the existence of the Meccans who converted to Islam. Second, close to people around. Rasulullah saw. is a person who is close to his family, friends, and even his people. As a leader, he always pays attention to the condition of his people because he does not want to leave them in trouble. All the needs, desires, complaints of the people were always heard by the Prophet Muhammad. Third, always discuss. Aisyah ra. once said, she never saw someone who consulted more than the Messenger of Allah. From this statement, it can be said that the Prophet Muhammad liked to consult. Another proof is that when Allah did not send down revelations about an issue, the prophet did not hesitate to conduct deliberations with his companions, in fact, he often preferred the results of the deliberation rather than sticking to his own opinion. ${ }^{16}$ Fourth, likes to give praise and respect others. Rasulullah saw. likes to praise his companions. He also called his companions by nicknames beginning with abun or ummun to honor them. The Prophet is also a person who is open to associating with anyone.

\section{The Prophet's Leadership Style}

Leadership style is a pattern of strategic behavior that is preferred and often set by a leader. ${ }^{17}$ Leadership style can also be interpreted as a leader's behavior in the decisionmaking process and problem-solving by one's leadership style. Therefore, it can be concluded that leadership style is a behavior used by a person to influence other people or

${ }^{14}$ Daniel Nawoseing'ollan and Josse Roussel, 'Influence of Leadership Styles on Employees' Performance: A Study of Turkana County, Kenya', International Journal of Business and Social Science, 8.7 (2017), 82-98<www.ijbssnet.com>.

${ }^{15}$ Zaen Musyirifin, 'Implementasi Sifat-Sifat Rasulullah Dalam Konseling Behavioral', Al - Irsyad : Jurnal Bimbingan Konseling Islam, 11.2 (2020), 151-59.

16 Bustami Saladin, 'Prinsip Musyawarah Dalam Al Qur'an', El-'Umdah, 1.2 (2018), 117-29 <https://doi.org/10.20414/el-umdah.v1i2.533>.

17 Muhammad Charis F and others, 'Kategori Kepemimpinan Dalam Islam', Jurnal Edukasi Nonformal, 1.2 (2020), 171-89. 
the person being led to achieve a goal. ${ }^{18}$ While the Islamic leadership style is described by the figure of the Prophet Muhammad. In addition to being a messenger of God, he is also an extraordinary head of state and head of household.

The leadership of the Prophet, as a leader, starting from the bottom to the top and from all corners of various cultures into one community/ummahan wahidah who believes and is pious. As a force, this appears in the battle of Badr where the Muslims were able to defeat the Quraysh Jahili army, thus gaining victory, not because of a miracle of the prophet. But more because of the leadership of the Prophet who succeeded in instilling faith, piety, loyalty, and fighting spirit to defend the truth and defend rights in addition to getting help from Allah swt.

The nature of democratic leadership of the Prophet Muhammad shown by his perseverance in educating his friends to be prepared as potential successors as leaders of the ummah in their worldly affairs and allowing them to develop themselves without worrying about being rivaled. The nature of this democratic leadership, he will not one of his friends to become the "crown prince". Who will be his successor to lead the people and the country he built after he is not left entirely to the will of the people themselves. ${ }^{19}$

The democratic nature of the leadership of the Prophet was also shown by his open attitude towards criticism and listening to the opinions and suggestions of others. The attitude of the Prophet's openness to criticism can be proven in events; "A friend once criticized the distribution of Ghanimah's property from one of the wars that occurred". The Messenger of Allah accepted the criticism with an open chest, even though it was not true. The attitude of accepting criticism and suggestions from others is shown by the hadith "accept advice even if it comes from a black slave".

The leadership style of the Prophet Muhammad was also shown when he made decisions that always carried out deliberation with friends and always did not act authoritarian. Presumably, it should be noted in the deliberation process as determined by the Messenger of Allah everyone has the right to express an opinion on something that is the subject of the problem he never behaves or shows signs that he is more dominant than his friends as a partner in making any important decisions. In his leadership, the Prophet used a persuasive or inviting approach that was not violent or repressive. We can see this from the attitude of our prophet in dealing with Bedouin people who have just converted to Islam and are still having a hard time leaving their bad temper.

\section{E. Applying Islamic Leadership Style Today}

In an era like now, a leader has several styles in carrying out an organization or institution including autocratic, democratic, laissez-faire, charismatic, transformational, and transactional. In the era of the millennial generation, there are more upheavals and

${ }^{18} \mathrm{~F}$ and others.

19 Mubasyaroh Mubasyaroh, 'Pola Kepemimpinan Rasulullah: Cerminan Sistem Politik Islam', Politea, 1.2 (2018), 95 <https://doi.org/10.21043/politea.v1i2.4488>. 
challenges to have leaders who are in line with current developments. ${ }^{20}$ As each leadership style certainly has its advantages and disadvantages. However, in Islam, the limits or categories of good leadership have been determined. In this case, Islamic leadership is not an authoritarian leadership, because Islam has shown its characteristics to be in the middle with the principle of balance. ${ }^{21}$

The peculiarity of Islamic leadership is in balance with the application of syura or deliberation, Rasulullah saw. exemplifies by always applying this deliberation in every matter such as state affairs, wars, and the public benefit. ${ }^{22}$ Islam provides a concept or understanding of the leader with a broad meaning, not just the achievement of goals and the participation of members. Islamic leadership is an effort to reveal the personality of the Prophet Muhammad in carrying out his leadership. There are several values applied by the Prophet Muhammad when it comes to being a leader, namely: leadership qualities, courage and firmness, self-control, patience and endurance, justice and equality, excellent personality, truth, and nobility of purpose. These values are the key to the success of the leadership of the Prophet Muhammad thus giving rise to the nature of obedience and voluntary following of his people.

In Islam, the condition for a person to be a leader is Muslim, has mental privileges, physical abilities, and spiritual degrees. This requirement is an individual qualification to be appointed as a leader. Meanwhile, if viewed by nature, a leader must have characteristics including physical strength and nervous system, appreciation of direction and purpose, enthusiasm, hospitality, integrity, technical expertise, decision-making ability, intelligence, leadership skills, and trust. ${ }^{23}$ In Islamic Leadership, the leader's behavior is also a reference, therefore a leader will be used as an example by his members, good leader behavior, high standards of values and ethics, and his actions towards others or groups, with this will certainly attract support and cooperation from members to obey and respect a leader. Islamic leaders hold legal responsibility for themselves and their members in carrying out their activities, therefore, in cooperating with members, it is not allowed to act arbitrarily, and must be carried out with humane methods

\section{F. Conclusion}

A good leader according to Islam is a faithful leader, and has qualities that can be imitated from the Prophet Muhammad. These traits include siddiq (true), fatonah (intelligent), tabligh (deliver), amanah (trustworthy), hard worker, high commitment, and many more. The leadership style of the Prophet Muhammad is relevant in every age, even in the end times like today. The leadership style is like a democratic attitude, being fair, not

20 Rodi Dwi Priono, 'Kepemimpinan Millennial: Strategi Faktor Internal (Human Resource, Marketing, Finance, Operational) Start-up Rumah Harmonis Menuju Keberhasilan', in Pemuda Dan Gaya Kepemimpinan Di Era Milenial, ed. by Galih Prabaningrum (Yogyakarta: Buana Grafika, 1369).

${ }^{21}$ Wahyu Hidayat and others, 'Kepemimpinan Dalam Perspektif Islam', El-Hikmah, 14.1 (2020), 98-111.

22 Bustami Saladin, 'Prinsip Musyawarah Dalam Al Qur'an', El-'Umdah, 1.2 (2018), 117-29 <https://doi.org/10.20414/el-umdah.v1i2.533>.

${ }^{23}$ Wahyu Hidayat and others, 'Kepemimpinan Dalam Perspektif Islam', El-Hikmah, 14.1 (2020), 98-111. 
authoritarian, and always applying deliberation in making decisions. Therefore, today's leaders should apply the leadership style of the Prophet Muhammad in leading his group.

\section{REFERENCES}

Abdullatif, Bashir, and Mohd Farid Mohd Sharif, 'Leadership in Islam: Views, Methods, and Suggestions in the Nigerian Islamic Organization', International Journal of Academic Research in Business and Social Sciences, 10.3 (2020), 174-82 <https://doi.org/10.6007/ijarbss/v10-i3/7036>

Abdulrheem, Jaman, and Hamdan Alzahrani, 'Prophet Muhammad' s Leadership and the Leadership of the Modern Saudi Arabia', International Journal of Business Social Science, 8.8 (2017), 160-63

Afriansyah, Ade, 'Konsep Pemimpin Ideal Menurut Al-Ghazālī', Nalar: Jurnal Peradaban Dan Pemikiran Islam, 1.2 (2018), 82 <https://doi.org/10.23971/njppi.v1i2.905>

Azis, Ilhamda, 'Keteladanan Sifat Rasullah Muhammad saw. Dalam Etika Profesi Akuntan

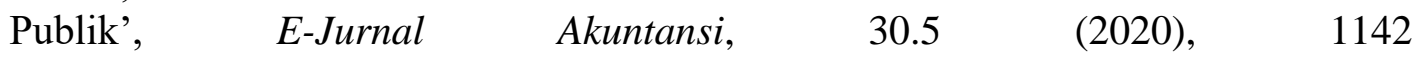
<https://doi.org/10.24843/eja.2020.v30.i05.p06>

F, Muhammad Charis, Muhammad Ammar A, Danar Wijokongko, and Muhammad Faza Al-, 'Kategori Kepemimpinan Dalam Islam', Jurnal Edukasi Nonformal, 1.2 (2020), 171-89

Hidayat, Wahyu, Muhammad Olifiansyah, Muhammad Dzulfiqar, and Bimansyah Putra Diaying, 'Kepemimpinan Dalam Perspektif Islam', El-Hikmah, 14.1 (2020), 98111

Mardliyah, Watsiqotul, S. Sunardi, and Leo Agung, 'Peran Manusia Sebagai Khalifah Allah Di Muka Bumi: Perspektif Ekologis Dalam Ajaran Islam', Jurnal Penelitian, 12.2 (2018), 355 <https://doi.org/10.21043/jp.v12i2.3523>

Mohsen, Nayal Rashed Mukred, 'Leadership from The Qur'an Relationship Between Taqwa, Trust and Business Leadership Effectiveness' (University Sains Malaysia, 2007) <http://digilib.unila.ac.id/4949/15/BAB II.pdf>

Mubasyaroh, Mubasyaroh, 'Pola Kepemimpinan Rasulullah: Cerminan Sistem Politik Islam', Politea, 1.2 (2018), 95 <https://doi.org/10.21043/politea.v1i2.4488>

Musyirifin, Zaen, 'Implementasi Sifat-Sifat Rasulullah Dalam Konseling Behavioral', Al Irsyad: Jurnal Bimbingan Konseling Islam, 11.2 (2020), 151-59

Nawoseing'ollan, Daniel, and Josse Roussel, 'Influence of Leadership Styles on Employees' Performance: A Study of Turkana County, Kenya', International Journal of Business and Social Science, 8.7 (2017), 82-98 <www.ijbssnet.com>

Priono, Rodi Dwi, 'Kepemimpinan Millennial : Strategi Faktor Internal (Human Resource, Marketing, Finance, Operational) Start-up Rumah Harmonis Menuju Keberhasilan', in Pemuda Dan Gaya Kepemimpinan Di Era Milenial, ed. by Galih Prabaningrum (Yogyakarta: Buana Grafika, 1369)

Rahayuning Tyas, Nashria, 'Model Kepemimpinan Pendidikan Nabi Muhammad Saw', Muslim Heritage, 4.2 (2019) <https://doi.org/10.21154/muslimheritage.v4i2.1851>

Sakdiah, 'Karakteristik Kepemimpinan Dalam Islam ( Kajian Historis Filosofis ) Sifat- 


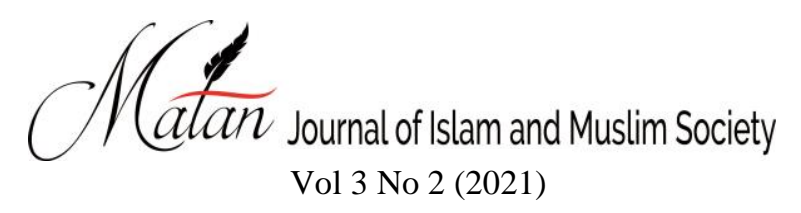

Sifat Rasulullah', Jurnal Al-Bayan, 22.33 (2016), 29-49

Saladin, Bustami, 'Prinsip Musyawarah Dalam Al Qur'an', El-'Umdah, 1.2 (2018), 117$29<$ https://doi.org/10.20414/el-umdah.v1i2.533>

Shukri Hanapi, Mohd, 'From Jahiliyyah To Islamic Worldview: In A Search Of An Islamic Educational Philosophy', International Journal of Humanities and Social Science, 3.2 (2013), 213-21

Umam, Muhamad Khoirul, 'Imam Para Nabi : Menelusur Jejak Kepemimpinan Dan', 60 Jurnal Al-Hikmah, 6 no. (2018), 59-74 